\title{
MEMBANGUN BUDAYA BACA MELALUI PENGELOLAAN MEDIA SUDUT BACA KELAS DENGAN "12345"
}

\author{
Mijiatun Sri Hartyatni \\ Cabang Dinas Pendidikan Provinsi Jawa Timur Wilayah Sidoarjo \\ e-mail:mijiatun@gmail.com
}

\begin{abstract}
Abstact: Classroom reading media management with"12345" can build a reading culture in the school because the existence of a classroom reading media is a place where students can perform read activities that are easily affordable and time efficient. The reading and reading practice is done by students and supervision by consistent and continuous interview, observation, assessment and monitoring by Master (Bahasa Indonesia Teachers). Through management with " 12345 " consists of 1).Socialization, 2) reading, 3). individual and group assignment, 4). Assessment and 5). reflection, requires students to conduct reading activities from reference books and/or other technologies programmed, scheduled and in a pleasant atmosphere. The result of media management reading classroom reading with " 12345 " in written or orally are reported and acted upon, thus building a reading culture in school.
\end{abstract}

Keywords: building reading culture, management, reading media classroom

\begin{abstract}
Abstrak: Pengelolaan media sudut baca kelas dengan "12345" dapat membangun budaya baca di Sekolah karena keberadaan media sudut baca kelas merupakan tempat dimana siswa dapat melakukan aktifitas membaca yang mudah terjangkau dan efisien waktu. Upaya pembudayaan/pembiasaan membaca ini dilakukan oleh siswa serta pengawasan dengan metode wawancara, pengamatan, penilaian dan pemantauan secara konsisten dan berkelanjutan oleh Guru (Guru Bahasa Indonesia). Melalui pengelolaan dengan "12345" terdiri dari 1) sosialisasi, 2) membaca, 3) tugas individu dan kelompok, 4) penilaian dan 5) refleksi, menghendaki siswa melakukan kegiatan membaca dari buku-buku referensi dan atau tehnologi lainnya secara terprogram, terjadwal dan dalam suasana yang menyenangkan.Hasil pengelolaan media sudut baca kelas dengan"12345" secara tertulis atau lisan dilaporkan dan ditindaklanjuti, sehingga terbangun budaya baca di sekolah.
\end{abstract}

Kata kunci : membangun budaya baca, pengelolaan, media sudut baca kelas

\section{PENDAHULUAN}

Pendidikan diselenggarakan sebagai suatu proses pembudayaan dan pemberdayaan peserta didik yang berlangsung sepanjang hayat, Pendidikan diselenggarakan dengan memberi keteladanan, membangun kemauan, dan mengembangkan kreativitas peserta didik dalam proses pembelajaran dan pendidikan diselenggarakan dengan mengembangkan budaya membaca, menulis dan berhitung bagi segenap warga masyarakat (UU NO 20 Tahun 2003, pasal 4). Jadi mengembangkan budaya literasi (membaca, menulis dan berhitung) sudah ada dalam sistem Pendidikan di Indonesia sejak tahun 2003, maka sebagai salah satu pengendali mutu layanan Pendidikan harus terus mengoptimalisasi pelayanannya untuk peningkatan mutu Pendidikan yang jauh lebih baik.

Dalam perkembangannya Pendidikan dituntut dapat memberikan pelayanan prima dalam menyiapkan ketrampilan abad 21 bagi Siswa. Penyiapan ketrampilan abad 21 bagi siswa menjadi tanggungjawab kita bersama sebagai komponen penjamin mutu Pendidikan. Pendidikan yang diselenggarakan harus dapat mewujudkan siswa yang literat sehingga mampu menghadapi tantangan masa depan untuk dirinya, orang tua dan masa depan Bangsa ini. Salah satu upaya membangun 
budaya baca dikalangan siswa adalah melalui pengelolaan yang tepat dan konsisten agar menjadi pembangunan budaya yang berkelanjutan serta dalam suasana menyenangkan. Dihadapkan pada kenyataan bahwa penyelenggaraan Pendidikan masih belum optimal dalam menyiapkan ketrampilan abad 21 menjadi siswa yang literat dengan permasalahanpermasalahan disekolah seperti: 1) minimnya tempat untuk melakukan aktifitas baca yang mudah dijangkau dan efisien waktu, 2) rendahnya minat membaca, menulis dan berhitung di kalangan siswa dan guru, 3) kurangnya pendampingan oleh guru dalam upaya membangun budaya baca di sekolah, 4) tidak optimalnya apresiasi dan penilaian guru terhadap siswa dalam meningkatkan kompetensi ketrampilannya untuk membangun budaya baca 5) tidak dilakukan monitoring dan evaluasi terhadap pelaksanaan program kegiatan pembangunan budaya baca untuk pengelolaan yang lebih baik. Berpijak pada permasalahan-permasalahan diatas maka penulis mencoba untuk menghadirkan sebuah solusi untuk membangun budaya baca di sekolah dengan pengelolaan terhadap tempat dimana Siswa bisa terbangun budaya bacanya dan efisien waktu dengan langkah-langkah: 1) sosialisasi, 2) membaca, 3) tugas individu dan kelompok, 4) penilaian, 5) refleksi, yang penulis sebut dengan"12345" dalam judul karya tulis: "membangun budaya baca melalui pengelolaan media sudut baca kelas dengan"12345".

\section{KAJIAN PUSTAKA}

Budaya baca adalah bagian dari budaya literasi yang meliputi membaca, menulis dan berhitung. Membudayakan atau membiasakan untuk membaca, menulis itu perlu proses jika memang dalam suatu kelompok masyarakat kebiasaan tersebut memang belum ada atau belum terbentuk. Ada banyak cara untuk membentuk budaya literasi diantaranya (dekat, mudah, murah, senang, lanjut), 1). pendekatan akses fasilitas baca (buku dan non buku), 2) kemudahan akses mendapatkan bahan bacaan, 3) murah/tanpa biaya (g, 4) menyenangkan dengan segala keramahan, 5) keberlanjutan/Continue/istiqomah. Membaca bagi sebagian masyarakat (komunitas) memiliki berbagai kendala dan kendalanya ini yang perlu ditangani secara bersama, jika tidak, maka kekuatan pribadi tidak akan mampu menjebol tembok pertahanan arus informasi yang mengglobal. Pemerintah, swasta, masyarakat, sekolah, aparat, dan kelompok jika bersama sama maka akan menjadi kekuatan besar untuk sama sama menyadari pentingnya literasi bagi kemajuan dan kecerdasan masyarakat menuju Indonesia cerdas seutuhnya. (Kutipan tulisan Trini Haryanti, Rumah Dunia Serang Banten, 2014)

Secara historis, Menurut Prof. Dr. Tarwotjo M.Sc sebagaimana dikutip oleh Asul Wiyanto dalam pengantar bukunya yang berjudul "Terampil Menulis Paragraf", produk dari aktivitas Literasi berupa tulisan, adalah sebuah warisan intelektual yang tidak akan temukan di zaman prasejarah. Dengan kata lain, apabila tidak ada tulisan, sama saja kita berada di zaman prasejarah. Tulisan merupakan bentuk rekaman sejarah yang dapat diwariskan dari generasi ke generasi, bahkan hingga berabad-abad lamanya. Dalam sejarah peradaban islam, dapat melihat bagaimana tradisi Literasi islam melahirkan tulisan-tulisan para pemikir dan ulama islam klasik yang sudah berumur ratusan tahun sampai saat ini masih eksis dipelajari di berbagai lembaga pendidikan islam, khususnya pesantren. Kitab-kitab yang ditulis para ulama dan intelektual muslim era klasik merupakan sebuah warisan intelektual yang sangat berharga bagi pengembangan khazanah intelektual islam dari generasi ke generasi. Sebagai aktivitas Literasi, menulis adalah sebuah kegiatan mengungkapkan ide atau gagasan secara 
tertulis. Orang yang melakukan kegiatan menulis disebut dengan penulis. Sedangkan hasil kegiatan menulis tersebut dinamakan tulisan. Sejarah mencatat bahwa yang menjadi benang merah antara zaman pra-sejarah dengan zaman sejarah adalah tulisan. Zaman prasejarah merupakan zaman di mana saat itu belum ada tulisan, sehingga segala peristiwa dan fenomena yang terjadi kala itu tidak dapat diketahui oleh generasi selanjutnya. Ditemukannya tulisan sebagai bukti adanya peradaban Literasi di masa lampau merupakan babak baru dimulainya zaman sejarah. Konsep Dasar Literasi terdiri dari :1. Literasi Dasar, mengembangkan kegiatan membaca, menulis, dan berhitung; 2. Literasi Perpustakaan, menggalakkan kegiatan literasi dengan menggunakan referensi yang ada diperpustakaan; 3. Literasi Teknologi, menggunakan kemajuan teknologi untuk memudahkan kegiatan literasi; 4. Literasi Media, menggunakan media sebagai media promosi literasi. Media terbagi menjadi media online seperti pembuatan blog yang akan melink ke website, facebook dan twitter. Sementara media cetak bisa dilakukan dengan bekerjasama dengan koran agar menyediakan kolom khusus untuk bagi karya anak, seperti puisi, karangan bebas, cerita bergambar, dan sebagainya. Atau bekerja sama dengan stasiun TV dan radio untuk menyiarkan dan mengampanyekan gerakan literasi; 5 . Literasi Visual, kemampuan untuk mengapresiasi, design grafis dan teks visual

Pengelolaan itu berakar dari kata "kelola" dan istilah lainnya yaitu "manajemen" yang artinya ketatalaksanaan, tata pimpinan. Menurut Bahri dan Zain (1996) bahwa pengelolaan itu adalah pengadministrasian, pengaturan atau penataan suatu kegiatan. Pengelolaan merupakan terjemahan dari kata "management". Terbawa oleh derasnya arus penambahan kata pungut kedalam
Bahasa Indonesia, istilah Inggris tersebut lalu di Indonesiakan menjadi "manajemen" atau "menejemen". Seiring pendapat diatas menurut Kamus Besar Bahasa Indonesia (1958, hlm. 412) disebutkan bahwa pengelolaan berarti penyelenggaraan.

Sudut baca merupakan sebuah tempat yang terletak di sudut ruangan yang dilengkapi dengan koleksi buku. Kemendikbud, (2016:17) menjelaskan bahwa sudut baca merupakan sebuah ruangan yang terletak disudut kelas yang dilengkapi dengan koleksi buku dan berperan sebagai perpanjangan fungsi perpustakaan. Melalui sudut baca siswa dilatih untuk membiasakan membaca buku, sehingga menjadikan siswa gemar membaca. Sudut menurut Gipayana (2011:2) adalah sebuah ruangan yang menyediakan buku-buku dengan jumlah banyak atau sedikit untuk dibaca, dipinjam, dan untuk melakukan aktivitas membaca. Kemendikbud (2016:13) juga menjelaskan bahwa sudut baca yaitu suatu sudut atau tempat yang berada didalam kelas yang digunakan untuk menata buku atau sumber belajar lainnya dalam rangka meningkatkan minat baca dan belajar siswa melalui kegiatan membaca yang menyenangkan. Sehingga dapat disimpulkan bahwa Media Sudut Baca Kelas adalah tempat atau ruangan disudut kelas yang dilengkapi dengan media yang dapat digunakan untuk melakukan aktivitas membaca, menulis dan berperan sebagai perpustakaan kecil yang mudah dijangkau oleh siswa serta menyenangkan.

Istilah "12345" adalah istilah yang penulis gunakan dan merupakan langkah-langkah pengelolaan yang diharapkan mudah untuk dilakukan oleh Guru sebagai pendamping dan pelaku penilaian terhadap kinerja yang dilakukan siswa dalam upayanya membudayakan kegiatan membaca melalui media sudut baca kelas. Pengelolaaan media sudut baca kelas dengan "12345" yang meliputi:1) sosialisasi, 2). Membaca, 3). 
Tugas Individu dan kelompok, 4). Penilaian dan , 5). Refleksi.

Hasil Penulisan (Ane Permatasari,

Dosen Prodi Ilmu Pemerintahan Fisipol,Universitas Muhammadiyah Yogyakarta, 2015) "Membangun Kualitas Bangsa Dengan Budaya Literasi." Bahwa, Tingkat literasi masyarakat suatu bangsa memiliki hubungan yang vertical terhadap kualitas bangsa. Tingginya minat membaca buku seseorang berpengaruh terhadap wawasan, mental, dan prilaku seseorang. Bangsa Indonesia adalah bangsa dengan tingkat literasi yang masih rendah padahal sudah 70 tahun sejak Indonesia menjadi negara merdeka. Ada banyak faktor kenapa literasi masyarakat Indonesia memilki persentase yang rendah. Permasalahan ini harus segera mendapatkan perhatian serius dari pemerintah. Bagaimana wacana mengenai 'melek bacaan' menjadi perhatian serius dalam semua kalangan masyarakat. Ketika keadaan melek bacaan menjadi sebuah budaya di Indonesia maka bukanlah mustahil untuk menjadi bangsa yang tidak hanya berhasil berkembang tetapi juga sebagai bangsa yang maju.

Penulisan tentang "Menumbuhkan Budaya Literasi Di Sekolah Dengan Program Kata" yang ditulis oleh Supiandi, S.Pd, Kepala Sekolah SMA Muhammadiyah Toboali Kabupaten Bangka Selatan. Penumbuhan Budaya Literasi di sekolah dengan Program Kata merupakan implementasi program dari (1) E-Puskata, (2) Mentoring Kata, dan (3) Arisan Kata memberikan kesimpulan bahwa, program kata dapat dijadikan alternatif pilihan dalam tahap pembiasan budaya membaca dan menulis (literasi) di sekolah dengan penerapan pada kegiatan revitalisasi perpustakaan baik dalam pengadaan buku, seting tempat, pelibatan publik dan reward(penghargaan) pada program e-puskata. Kegiatan peserta didik untuk menggiring pemahaman tentang pentingnya membaca dan menulis (literasi) melalui aktivitas "kelas literasi" dan "jurnal literasi" dalam program mentoring kata. serta kegiatan pembiasan guru dalam membaca dan menulis (literasi) dengan program "arisan kata".

\section{METODE PENELITIAN}

Yang menjadi subyek dalam penulisan karya tulis ini adalah Guru dan Siswa pada sekolah binaan di wilayah kabupaten Sidoarjo provinsi Jawa Timur. Sedangkan obyek penulisan karya tulis ini adalah Pengelolaan Media Sudut Baca Kelas dengan "12345", yang terdiri : 1). Sosialisasi, 2). Membaca, 3). Tugas Individu dan Kelompok, 4). Penilaian, 5) Refleksi. Jadi “12345" mengartikan lima langkah membangun budaya baca dengan Media Sudut Baca Kelas. Waktu pelaksanaan rencana kegiatan dalam upaya membangun budaya baca siswa dan guru di Satuan Pendidikan yang menjadi wilayah tugas penulis dimulai pada awal semester Tahun pelajaran 2017/2018 saat rapat koordinasi yang selalu dilakukan setiap awal semester pada setiap tahun pelajaran.

\section{Metode Pengumpulan Data}

\section{Wawancara}

Wawancara penulis menggunakan pedoman wawancara kepada Kepala Sekolah, Wakil Kepala Sekolah dan Guru Bahasa Indonesia untuk mendapatkan data tentang apakah budaya baca sudah dilaksanakan di sekolah-sekolah binaan, kendala yang dijumpai saat pelaksanaan budaya baca di sekolah, bagi yang sudah melaksanakan, pendapat bapak/ibu tentang pembuatan media sudut baca kelas

2. Obsevasi/ pengamatan

Observasi awal penulis lakukan untuk memperoleh data tentang keberadaan Media Sudut Baca pada sekolah binaan di Kabupaten Sidoarjo dan observasi untuk mendapatkan data sekolah yang telah melaksanakan pembudayaan/pembiasaan budaya membaca baik untuk Guru maupun pada Siswa

3. Supervisi 
Supervisi dilaksanakan dengan menggunakan 1) data guru Bahasa Indonesia setiap sekolah pada sekolah binaan dan jumlah ruang kelas $\mathrm{X}, 2$ ) langkah membaca dengan program bacaan pada media sudut baca kelas, 3) pengelolaan media sudut baca kelas dengan "12345", 4). rencana pelaksanaan penilaian, 5). rencana penilaian kinerja siswa yang dilakukan guru Bahasa Indonesia untuk melihat capaian siswa sebagai indikator keberhasilan bahwa pengelolaan media sudut baca kelas dengan "12345" dapat membangun budaya baca.

4. Monitoring dan Evaluasi (Monev)

Monitoring dilaksanakan dengan menggunakan instrumen monitoring sedangkan evaluasi dilaksanakan setelah lima langkah dalam pengelolaan Media Sudut Baca Kelas telah dilaksanakan dan disampaikan kepada Kepala Sekolah.

\section{HASIL DAN PEMBAHASAN}

Hasil Sosialisasi Membangun Budaya Baca Dengan Media Sudut Baca Kelas

Sosialisasi membangun budaya baca disampaikan pada saat kegiatan awal semester tahun pelajaran 2017/2018 yang dihadiri oleh semua Kepala Sekolah binaan penulis dan satu wakil Kepala Sekolah yang berjumlah 9 Kepala Sekolah dan 9 wakil Kepala Sekolah jumlah keseluruhan 18 orang. Selain materi lain disampaikan materi sosialisasi literasi sekolah yaitu penyampaian program oleh Pengawas dalam rangka pengembangan Satuan pendidikan melalui Budaya Literasi di Sekolah, dimasukkannya kegiatan Budaya Literasi di sekolah dalam Dokumen I sesuai dengan lampiran Permendikbud No 23 tahun 2015 tentang Penumbuhan Budi Pekerti bahwa, kegiatan wajib untuk mengembangkan potensi diri peserta didik secara utuh, menggunakan 15 menit sebelum hari pembelajaran untuk membaca buku selain buku mata pelajaran (setiap hari), karena setiap siswa mempunyai potensi yang beragam.
Sekolah hendaknya memfasilitasi secara optimal agar siswa bisa menemukenali dan mengembangkan potensinya. Dari sinilah maka sosialisasi tentang ide/gagasan penulis tentang bagaimana membangun budaya baca dengan pembuatan Media Sudut Baca Kelas yang dimulai pada ruang kelas $\mathrm{X}$, pendanaan, dan program pengelolaan Media Sudut Baca Kelas.

\section{Hasil Sosialisasi Membangun Budaya Baca Melalui Program Pengelolaan Media Sudut Baca Kelas}

$$
\text { Membangun Budaya Baca }
$$

melalui pengelolaan Media Sudut Baca Kelas disampaikan kepada Kepala Sekolah, Wakil Kepala Sekolah dan Guru Bahasa Indonesia untuk ditindaklanjuti menjadi program pengelolaan yang dikoordinir oleh Guru (Guru Bahasa Indonesia) melalui kegiatan-kegiatan yang akan menjadi aktifitas membaca di Media Sudut Baca kelas yang akan dibuat dimulai ditiap ruangan kelas $X$. Penyampaian sosialisasi ini pada sekolah masing-masing yang penulis kunjungi, dengan memanggil guru Bahasa Indonesia. Penyampaian informasi kepada Guru Bahasa Indonesia tentang Pengelolaan Media Sudut Baca Kelas dengan "12345" dilakukan oleh Pengawas untuk mrndapatkan persepsi yang sama tentang bagaimana mengelola Media Sudut Baca Kelas dalam upaya membangun budaya baca. Menggunakan metode wawancara, dari hasil wawancara didapatkan beberapa tanggapan seperti dalam tabel hasil wawancara berikut :

Tabel 1. Hasil Wawancara dengan Guru

\begin{tabular}{|c|c|c|}
\hline No & Pertanyaan & Tanggapan \\
\hline 1. & $\begin{array}{l}\text { Apakah di sekolah Ibu dan } \\
\text { Bapak sudah dilaksanakan } \\
\text { kegiatan budaya baca? }\end{array}$ & $\begin{array}{l}\text { 1.1. "Sudah", (ada } 6 \text { sekolah) } \\
\text { 1.2. "Belum", (ada } 3 \text { sekolah) }\end{array}$ \\
\hline 2. & $\begin{array}{l}\text { Jika sudah, apa bentuk } \\
\text { kegiatan membangun } \\
\text { budaya baca di sekolah } \\
\text { bapak/ibu? }\end{array}$ & $\begin{array}{l}\text { 2.1." Membaca Alquran dan } \\
\text { terjemahan setiap pagi" } \\
\text { 2.2."Membaca buku } \\
\text { pelajaran pada jam pertama } \\
\text { selama } 10-15 \text { menit" } \\
\text { 2.3. "Membaca satu surat } \\
\text { pendek secara bergilir tiap } \\
\text { pagi sebelum pelajaran" } \\
\text { 2.4. "setiap minggu ada } 30 \\
\text { menit wajib berkunjung ke } \\
\text { Perpustakaan sekolah" } \\
\text { 2.5."Mengisi dan membaca } \\
\text { Mading sekolah" }\end{array}$ \\
\hline
\end{tabular}




\begin{tabular}{|c|c|c|}
\hline 3. & $\begin{array}{l}\text { Kendala yang dijumpai } \\
\text { saat pelaksanaan budaya } \\
\text { baca di sekolah, bagi yang } \\
\text { sudah melaksanakan? } \\
\text { ( Tanggapan berhubungan } \\
\text { dengan tanggapan } 2.1 \text { s.d } \\
2.5 \text { ) }\end{array}$ & $\begin{array}{l}\text { 3.1." Tidak komitmen } \\
\text { dengan waktu yang } \\
\text { digunakan" } \\
\text { 3.2. "Kurangnya koordinasi } \\
\text { dengan guru pada jam } \\
\text { pertama hari itu" } \\
\text { 3.3. "Ada yang tidak masuk } \\
\text { pas giliran baca tidak } \\
\text { dikomunikasikan/diberitahu" } \\
\text { 3.4. "Banyak yang lupa } \\
\text { waktu dan tidak ditegur" } \\
\text { 3.5. "Pengelolaan belum baik } \\
\text { dan konsisten" }\end{array}$ \\
\hline 4. & $\begin{array}{l}\text { Pendapat Bp/Ibu tentang } \\
\text { Pembuatan Media Sudut } \\
\text { Baca Kelas? }\end{array}$ & $\begin{array}{l}\text { 4.1. "Sangat setuju, karena } \\
\text { dekat dengan siswa } \\
\text { diruangan kelas" } \\
\text { 4.2. "setuju, karena mudah } \\
\text { dipantau oleh guru pada saat } \\
\text { pembelajaran" } \\
\text { 4.3. "setuju, kapan mau } \\
\text { dimulai membuatnya Bu?" } \\
\text { 4.4." Setuju, bagaimana dana } \\
\text { dan pengadaan bukunya } \\
\text { Bu?" }\end{array}$ \\
\hline 5. & $\begin{array}{l}\text { Pendapat Bp/Ibu jika } \\
\text { seluruh Guru Bahasa } \\
\text { Indonesia pada sekolah } \\
\text { binaan Pengawas } \\
\text { dikumpulkan untuk } \\
\text { membahas permasalahan } \\
\text { pembangunan budaya } \\
\text { baca? } \\
\text { (solusi pengelolaan Media } \\
\text { Sudut Baca Kelas } \\
\text { dengan"12345") } \\
\end{array}$ & $\begin{array}{l}\text { Rata-rata menjawab setuju, } \\
\text { agar saling berkomunikasi } \\
\text { dan sharing permasalahan } \\
\text { membangun budaya baca di } \\
\text { sekolah dengan diketahui } \\
\text { Pengawasnya. }\end{array}$ \\
\hline 6. & $\begin{array}{l}\text { Rencana pengelolaan } \\
\text { Media Sudut Baca Kelas } \\
\text { dengan"12345"di sekolah }\end{array}$ & $\begin{array}{l}\text { 6.1 satu masukan dari Guru } \\
\text { Bahasa Indonesia yang } \\
\text { mengatakan:" sebaiknya } \\
\text { pelaksanaannya tidak } \\
\text { menyita waktu tersendiri, } \\
\text { namun satu rangkaian dengan } \\
\text { kegiatan pembelajaran yang } \\
\text { penilaiannya dapat dilakukan } \\
\text { langsung oleh Guru mapel } \\
\text { pada saat pembelajaran tsb } \\
\text { berlangsung". }\end{array}$ \\
\hline
\end{tabular}

Pembahasan Pengelolaan Media Sudut Baca Kelas dengan Sosialisasi

Berdasarkan tabel diatas dari tanggapan hasil wawancara dengan Guru terhadap kegiatan membangun budaya baca di sekolah yaitu sebanyak $67 \%$ Sekolah telah melaksanakan kegiatan membangun budaya baca sesuai dengan situasi dan kondisi sekolah masingmasing dan sebanyak $33 \%$ belum melaksanakan kegiatan membangun budaya baca di sekolahnya, rata-rata sekolah setuju untuk dikumpulkannya seluruh Guru Bahasa Indonesia pada sekolah binaan untuk saling berkomunikasi dan berbagi pengetahuan serta pengalaman untuk rencana pengelolaan Media Sudut Baca Kelas dalam upaya membangun budaya baca di sekolah. Sosialisasi ini merupakan langkah untuk menjawab permasalahan pengembangan Satuan Pendidikan tentang minimnya tempat untuk melakukan aktifitas membaca yang mudah terjangkau dan efisien waktunya dalam upaya membangun budaya baca. Sehingga dengan sosialisasi tentang keradaan, fungsi dan program pengelolaan Media Sudut Baca Kelas diharapkan mampu untuk membangun budaya baca di Sekolah.

\section{Pembahasan Pengelolaan Media Sudut Baca Kelas Dengan Membaca}

Pengelolaan Media Sudut Baca Kelas dengan menggunakan langkah kedua yaitu membaca. Membaca pada kegiatan membangun budaya baca berdasarkan hasil wawancara dengan Guru Bahasa Indonesia pada Sekolah Binaan masih banyak kendala baik dari dalam siswa maupun sistem pengelolaan membangun budaya baca yang diterapkan di sekolah masih lemah dan belum konsisten untuk menindaklanjuti permasalahan-permasalahan yang muncul pada saat kegiatan membangun budaya baca berlangsung. Untuk itu pembahasan tentang pengelolaaan Media Sudut Baca Kelas dengan membaca dimulai dengan rencana program setelah langkah sosialisasi dilaksanakan. Pada pembahasan Pengelolaan $M S B K$ dengan langkah 2 yaitu membaca, dilaksanakan pada waktu yang telah disepakati bersama oleh guru Bahasa Indonesia atau Guru mapel lain bersama siswa di kelas. Pengelolaan Kegiatan membaca ini ditentukan bahan bacaan dengan tema tertentu yang disepakati dan dimasukkan dalam program pengelolaan membaca. Waktu yang dibutuhkan untuk kegiatan dalam langkah membaca ini ditentukan oleh guru disesuaikan dengan alokasi waktu pembelajaran guru yang bersangkutan. Alokasi waktu pada kegiatan membaca sebaiknya diinformasikan dan secara konsisten dilaksanakan sesuai waktu yang tersedia, jangan sampai masalah waktu menjadi permasalahan baru bagi guru maupun siswa dalam upaya membangun budaya 
baca. Pembiasaan yang baik untuk tepat waktu akan menjadi salah satu bukti komitmen untuk membangun budaya baca yang lebih baik. Bahan bacaan dapat diambilkan dari buku yang tersedia atau disediakan Sekolah di $M S B K$ dan atau dari tehnologi informasi lain, bisa koran, majalah, artikel, jurnal, brosur, telegram, kartu pos, internet dll. Format program pengelolaan Media Sudut Baca Kelas dengan membaca disepakati bersama siswa.

Tabel 2 tentang Pengelolaan Media Sudut Baca Kelas dengan Membaca

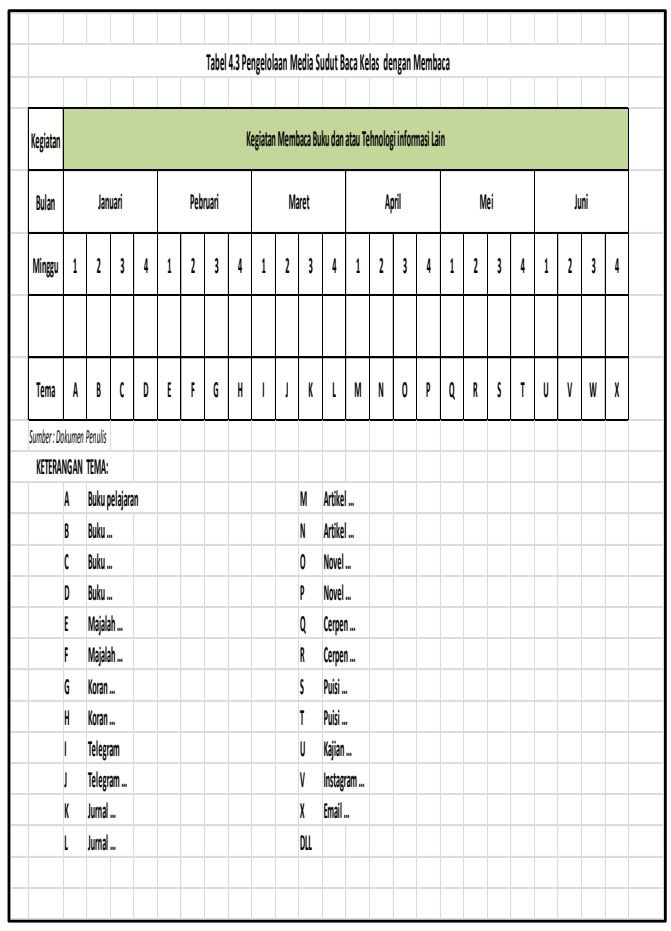

Berdasarkan tabel diatas, Pengelolaan Media Sudut Baca Kelas dengan Membaca memuat kegiatan membaca buku dan atau tehnologi informasi lain yang temanya ditentukan oleh guru atau hasil kesepakatan diawal semester. Hasil membaca ditulis dalam bentuk resume, hasil resume dinilai oleh guru Bahasa Indonesia pada akhir bulan dan dikembalikan untuk diletakkan pada tempat/ wadah per kelompok di Media Sudut Baca Kelas. Agar hasil resume dari siswa lain atau kelompok lain dapat dibaca dan diharapkan media ini bisa digunakan untuk saling memberikan masukan antar teman dalam satu kelompok atau lintas kelompok yang dikemas menjadi sebuah obrolan yang menyenangkan bagi mereka, dan berharap bisa membentuk pembiasaan yang membangun budaya baca yang baik.

\section{Pembahasan Pengelolaan Media Sudut Baca Kelas Dengan Tugas Individu dan Kelompok}

Permasalahan

kedua

pengembangan Satuan Pendidikan yang melatarbelakangi penulisan karya tulis ini adalah rendahnya minat membaca, menulis dan berhitung di kalangan Siswa dan Guru. Langkah 3 ini merupakan langkah pengelolaan Media Sudut Baca Kelas yang menghendaki Siswa mempunyai ketrampilan abad 21 sekaligus bagi Guru untuk pengembangan profesionalisme meningkatkan ketrampilan membuat soal HOTS ( Higher Order Thingking Skill ) dalam pemberian tugas. Dengan pemberian tugas individu dan kelompok secara terprogram, hasilnya diberikan apresiasi dalam bentuk nilai oleh Guru , dipajang di Media Sudut Baca Kelas yang bisa dilihat dengan mudah oleh semua Siswa baik dalam kelompoknya atau lintas kelompok, konsisten dan berkelanjutan maka hal ini akan menyiapkan Siswa memiliki ketrampilan abad 21 menjadi literat untuk membangun budaya baca Siswa dengan baik.

Tugas individu dan kelompok dilaksanakan pada saat pembelajaran dan atau pada waktu tertentu yang diagendakan untuk dipajang di Media Sudut Baca Kelas, tugas ini bisa diambilkan dari buku yang tersedia di Media Sudut Baca Kelas atau internet dengan fasilitas wifi sekolah. Pemberian tugas individu maupun kelompok dapat disampaikan oleh Guru (Guru Bahasa Indonesia) untuk dikerjakan siswa diluar jam pelajaran yang waktunya tidak dibatasi, tugas disampaikan diawal bulan dengan tugas setiap minggu berbeda, dan tugas bulan berikutnya disampaikan pada awal bulan berikutnya dan seterusnya. Rencana program pengelolaan langkah 
tugas individu dan kelompok sudah direncanakan dan dibuat oleh Guru (Guru Bahasa Indonesia) satu semester sekaligus, walau penyampainnya satu bulan- satu bulan. Hasil kinerja siswa atas tugas individu dan atau kelompok yang dibebankan kepadanya disampaikan nilainya pada minggu berikutnya dan seterusnya. Materi Tugas individu dan kelompok didasarkan pada materi pembelajaran mapel Guru (Guru Bahasa Indonesia) yang disesuaikan silabus. Berikut adalah contoh Format Tugas individu dan kelompok yang dibuat Guru (Guru Bahasa Indonesia) yang dapat dilihat pada tabel 3 tentang Format Tugas Individu dan kelompok. Satu Kelas dibuat menjadi 6 kelompok kerja siswa, dimaksudkan agar penataan hasil di Media Sudut Baca Kelas tidak rumit tuk kenali setiap siswa berada pada kelompok berapa, hal ini sekaligus membawa anak untuk pengorganisasian pembiasaan /pembudayaan baca yang baik.

Tabel 3. Format Tugas Individu dan Kelompok

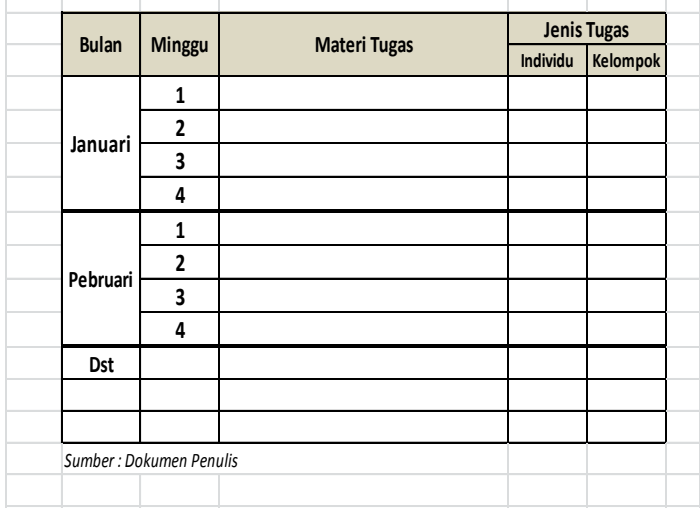

\section{Pembahasan Pengelolaan Media Sudut Baca Kelas Dengan Penilaian}

Pengelolaan Media Sudut Baca

Kelas dengan penilaian dilakukan oleh Guru (Guru Bahasa Indonesia) atas tugas dalam langkah 1.membaca, langkah 2.tugas individu dan kelompok. Menurut Permendikbud No 23 Tahun 2016 tentang Standar Penilaian dijelaskan bahwa Penilaian adalah proses pengumpulan dan pengolahan informasi untuk mengukur pencapaian hasil belajar peserta didik (pasall:2). Pembelajaran adalah proses interaksi antar peserta didik, antara peserta didik dengan pendidik dan sumber belajar pada suatu lingkungan belajar (pasall:3). Penilaian hasil belajar oleh Pendidik bertujuan untuk memantau dan mengevaluasi proses, kemajuan belajar, dan perbaikan hasil belajar peserta didik secara berkesinambungan (pasal4:1). Penilaian hasil belajar oleh Pendidik dilakukan dalam bentuk ulangan, pengamatan, penugasan dan/atau bentuk lain yang diperlukan (pasal 6:1).Penilaian ini harus dilakukan secara konsisten dan komitmen tinggi Guru untuk menilai kinerja Siswa yang hasilnya secara rutin disampaikan ke Siswa, hasil tugas serta hasil penilaian dipajang atau ditaroh di Media Sudut Baca Kelas sebagai bahan referensi tambahan bagi Siswa atau kelompok Siswa dalam kelompoknya maupun lintas kelompok. Langkah ini dimaksudkan juga sebagai langkah membangun budaya baca bagi Guru karena harus secara rutin mengapresiasi dan menilai kinerja siswanya yang akan menjadi bahan bacaan di Media Sudut Baca Kelas. Penilaian yang diterima Siswa diberikan bersamaan di lembar tugas individu dan kelompok yang diberikan ke Siswa untuk dipajang di Media Sudut Baca Kelas bersama kelompoknya dalam satu tempat. Pada setiap penilaian yang diberikan dalam satu bulan direkap hasilnya, rekapan hasil penilaian akan menjadi bahan rujukan evaluasi dalam langkah refleksi dan capaian siswa dalam satu bulan akan terlihat hasilnya

dan dipergunakan untuk memantau perkembangan apakah budaya baca sudah terbangun dengan baik melalui pengelolaan Media Sudut Baca Kelas Dengan"12345".

Tabel 5. Format daftar penilaian kinerja siswa 


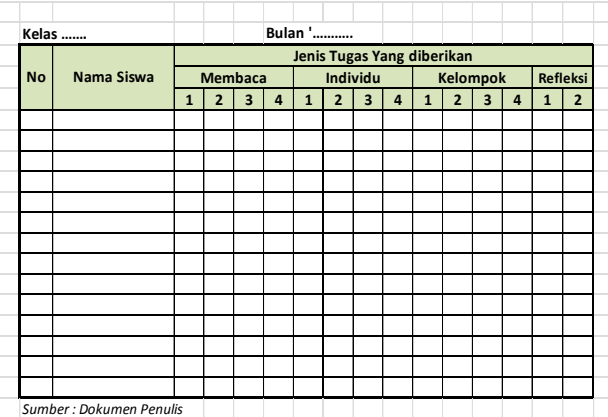

Keberhasilan kegiatan ini dalam upaya membangun budaya baca melalui pengelolaan Media Sudut Baca Kelas dengan"12345" dapat dilihat hasilnya dari hasil penilaian yang dibuat rata-rata setiap Siswa dalam satu bulan dan direkap hasilnya. Harapannya upaya membangun budaya baca akan terwujud dengan langkah 4 penilaian.

\section{Pembahasan Pengelolaan Media Sudut Baca Kelas Dengan Refleksi}

Refleksi dilaksanakan setelah keempat langkah -langkah dalam pengelolaan Media Sudut Baca Kelas selesai dilaksanakan pada batasan waktu tertentu. Refleksi sebagai suatu kegiatan yang dilakukan dalam proses belajar mengajar pada prinsipnya merupakan kegiatan untuk nilai peserta didik kepada pendidik. Penilaian tersebut dapat dilakukan secara tertulis maupun secara lisan oleh peserta didik kepada pendidiknya. Penilaian dari peserta didik dapat berisi ungkapan curahan hatinya yang berupa kesan, pesan, harapan serta kritikan yang bersifat membangun atas proses yang diterimanya sejak awal hingga akhir proses tersebut. Oleh sebab itu, kegiatan refleksi menjadi sangat penting, apalagi dalam perkembangan jaman saat ini yang penuh dengan tantangan menghadapi pengaruh globalisasi yang membawa pada perubahan sikap peserta didik maupun pendidik (Kutipan tulisan Hery Susilowati, Refleksi dalam Pendidikan)

Pelaksanaan refleksi dapat dilakukan pada kegiatan setelah satu bulan berlangsung, 3 bulan atau satu semester. Refleksi ini dimaksudkan untuk mendapatkan masukan dari Siswa atas pengelolaan Media Sudut Baca kelas dengan langkah sosialisasi, membaca, tugas individu dan kelompok maupun penilaian Guru. Langkah refleksi dapat dilakukan siswa dengan cara tertulis menggunakan lembar evaluasi kegiatan dan atau secara lisan pada kegiatan presentasi Siswa atau kelompok Siswa. Refleksi yang dilakukan secara lisan langsung ditulis pada saat kegiatan berlangsung.

Tabel 6. Format lembar evaluasi pengelolaan media sudut baca kelas

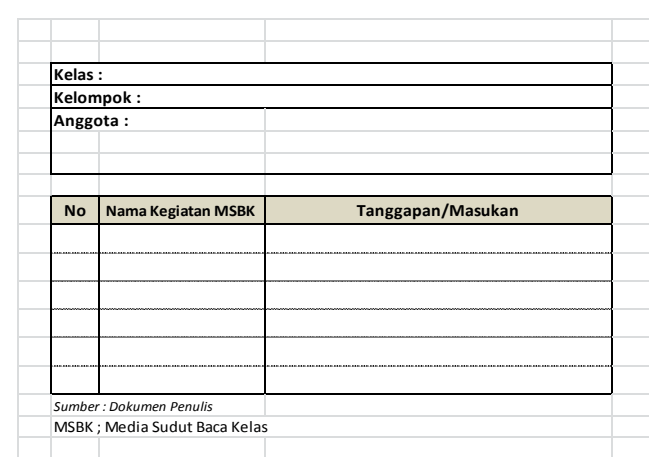

Tanggapan/masukan dari kelompok dikumpulkan dan direkap dalam satu format tersendiri dan menjadi bahan evaluasi pelaksanaan pengelolaan Media Sudut Baca Kelas dengan"12345" yang disampaikan kepada atasan untuk ditindaklanjuti. Pengisian dapat menugaskan pada Siswa yang kompeten.

Tabel 7. Format hasil evaluasi kelompok semua kelas

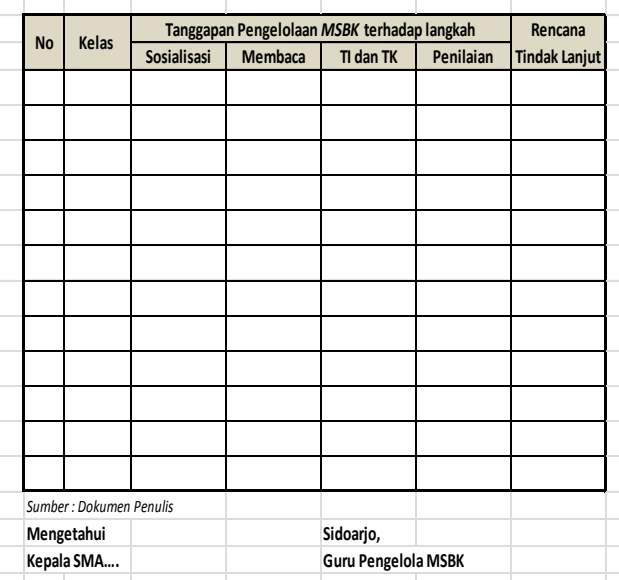

\section{Simpulan}

Keberadaan Media Sudut Baca Kelas adalah tempat dimana Siswa dapat melakukan aktifitas membaca yang 
mudah terjangkau dan efisien waktu. Pengelolaan Media Sudut Baca Kelas dengan "12345" adalah pengelolaan dengan menggunakan lima langkah yang terdiri dari 1).Sosialisasi, 2) Membaca, 3). Tugas individu dan kelompok, 4). Penilaian dan 5). Refleksi. Lima langkah dalam pengelolaan Media Sudut Baca Kelas menghendaki Siswa melakukan kegiatan membaca dari buku-buku yang tersedia di Media Sudut Baca Kelas, buku referensi yang ditugaskan Guru, bacaan lain selain buku dan dari berbagai tehnologi lainnya secara terprogram, terjadwal dan dalam suasana yang menyenangkan. Upaya pembudayaan/pembiasaan membaca ini dilakukan oleh Siswa serta pengawasan berupa pelaksanaan penilaian secara konsisten dan berkelanjutan oleh Guru (Guru Bahasa Indonesia) sehingga dapat membangun budaya baca di Sekolah.

Pengelolaan Media Sudut Baca Kelas dengan "12345" untuk langkah 1). sosialisasi, adalah sosialisasi Pengawas kepada Kepala Sekolah, wakil Kepala Sekolah dan guru Bahasa Indonesia yang hasilnya $100 \%$ disepakati tentang pembuatan Media Sudut Baca Kelas dan pengelolaannya. Sosialisasi Guru ( Guru Bahasa Indonesia) kepada Siswa tentang pengelolaan Media Sudut Baca Kelas akan menghasilkan Capaian Siswa dalam menghidupkan dan memeriahkan Media Sudut Baca Kelas yang merupakan bentuk aktualisasi bahwa budaya baca telah terbangun dengan baik. Langkah 2). Membaca, adalah program membaca buku di Media Sudut Baca Kelas dan atau tehnologi informasi lain sesuai program yang direncanakan. Pengelolaan bahan bacaan yang terprogram untuk Siswa akan membangun budaya baca di Sekolah dengan baik. Langkah 3). tugas individu dan kelompok, adalah tugas yang dilaksanakan oleh siswa/kelompok siswa sesuai program. Dengan pemberian tugas individu dan kelompok secara terprogram, hasilnya diberikan apresiasi dalam bentuk nilai oleh Guru, dipajang di
Media Sudut Baca Kelas yang tertata rapi dalam kelompok dan bisa dilihat dengan mudah oleh semua Siswa baik dalam kelompoknya atau lintas kelompok, konsisten dan berkelanjutan maka hal ini akan menyiapkan Siswa memiliki ketrampilan abad 21 menjadi literat untuk membangun budaya baca Siswa dengan baik. Langkah 4). Penilaian, adalah proses menilai atas kinerja Siswa di Media Sudut Baca Kelas melalui membaca, tugas dan refleksi yang dilakukan Guru (Guru Bahasa Indonesia) secara konsisten dan komitmen tinggi serta disampaikan secara rutin capaian siswa tersebut kepada atasan langsung akan membangun budaya baca siswa dengan baik. Langkah 5). Refleksi, adalah langkah yang dilakukan siswa secara tertulis dengan lembar evaluasi pengelolaan Media Sudut Baca Kelas yang diberikan Guru maupun secara lisan pada saat presentasi kelompok sebagai bahan evaluasi program. Refleksi yang dilakukan sebagai bahan evaluasi dan ditindaklanjuti akan menjadi upaya dalam mmbangun budaya baca terfasilitasi dengan baik.

\section{DAFTAR PUSTAKA}

Ane Permatasari, 2015. Membangun Kualitas Bangsa Dengan Budaya Literasi. Yogyakarta

http://id.wiktionary.org/wiki/pengelolaan, (diunduh tgl 7 November 2017)

https://sugionomuslimin.wordpress.com/2 010/konsep pengelolaan, (diunduh tgl 7 Nov 2017)

Menteri Pendayagunaan Aparatur Negara RB, 2016 . Peraturan Menteri Pendayagunaan Aparatur Negara dan Reformasi Birokrasi Nomor 021 Tahun 2010 tentang Jabatan Fungsional Pengawas Sekolah dan Angka Kreditnya, Jakarta: Departemen Pendayagunaan 
Aparatur Negara dan Reformasi Birokrasi.

Mendikbud, 2016. Permendikbud No 23 Tahun 2016 tentang Standar Penilaian Pendidikan Dasar dan Menengah, Jakarta:Departemen Pendidikan dan Kebudayaan.

Mendikbud, 2015. Permendikbud No 23 Tahun 2015 tentang Penumbuhan Budi Pekerti, Jakarta:Departemen Pendidikan dan Kebudayaan.

Presiden Republik Indonesia, 2003.Undang-Undang Nomor 20 Tahun 2003 tentang Sistem Pendidikan Nasional, Jakarta: Negara Republik Indonesia

Presiden Republik Indonesia, 2013. Peraturan Pemerintah No 32 Tahun 2013 tentang Perubahan atas Peraturan Pemerintah No 19 Tahun 2005 tentang SNP , Jakarta:Negara Republik Indonesia

Prof. Dr. Tarwotjo M.Sc sebagaimana dikutip oleh Asul Wiyanto dalam pengantar bukunya yang berjudul "Terampil Menulis Paragraf",

Supiandi, S.Pd, Kepala Sekolah SMA Muhammadiyah Toboali Kabupaten Bangka Selatan. 